\title{
Assessment of Some Heavy Metals Concentration and Antioxidant Activity in Barley Grain Cultivars and Their Malts from Iran
}

\author{
Naficeh Sadeghi',2,3, Mohammad Reza Oveisi' ${ }^{1}$ Behrooz Jannat ${ }^{3 *}$, Manan Hjimahmoodi', \\ Neda Malayeri' ${ }^{1}$, Masoomeh Behzad ${ }^{1}$ \\ ${ }^{1}$ Department of Drug and Food Control, School of Pharmacy, Tehran University of Medical Sciences, Tehran, \\ Iran \\ ${ }^{2}$ Water Health Research Center, Ministry of Health and Medical Education, Tehran, Iran \\ ${ }^{3}$ Halal Research Center, Ministry of Health and Medical Education, Tehran, Iran

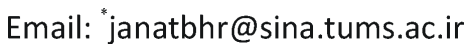

Received 16 May 2016; accepted 30 July 2016; published 2 August 2016

Copyright (C) 2016 by authors and Scientific Research Publishing Inc.

This work is licensed under the Creative Commons Attribution International License (CC BY). http://creativecommons.org/licenses/by/4.0/

(c) (i) Open Access

\section{Abstract}

Global industrialization could be considered as a major cause of environmental contamination with heavy metals. Barley and malt, vastly used in the food industries, are of no exception. Therefore, we aimed to measure the levels of trace elements Zinc, Copper and heavy metals Lead and Cadmium by Differential Pulse Anodic Stripping Voltammetry in 19 barley grain cultivars and their malts in Iran. Ferric reducing antioxidant power (FRAP) assay was also used for determination of antioxidant activity of the samples. The mean levels of $\mathrm{Zn}, \mathrm{Cd}, \mathrm{Pb}$ and $\mathrm{Cu}$ were measured to be $18.813 \pm 8.575,0.212 \pm 0.116,0.278 \pm 0.163,3.746 \pm 1.118 \mathrm{mg} / 100 \mathrm{~g}$ in the barley samples and $14.364 \pm 6.391,0.153 \pm 0.098,0.179 \pm 0.082$ and $3.033 \pm 1.392 \mathrm{mg} / 100 \mathrm{~g}$ in the malt samples, respectively. The highest concentration of $\mathrm{Zn}$ was measured in the Bahman cultivar of barley and Mb-82-4 sample of malt while the Sahra cultivar of barley and Valfajr sample of malt had the lowest concentration of $\mathrm{Pb}$ and the Nimrooz cultivar of barley and Rihane-03 sample of malt had the lowest concentration $\mathrm{Cu}$. The mean levels of zinc and lead in the evaluated samples of barley and the mean levels of zinc, lead and cadmium in the samples of malt were significantly lower than standard limits. Although not significant, the mean levels of cadmium in barley samples and copper in malt samples were higher than the standard limits, but the mean level of copper was found to be significantly higher than the standard limits in the samples of barley $(p=0.008)$. Antioxidant acitivity was found to be highest in the Mb-82-12 sample of malt and Nik cultivar of barley. The aver-

\footnotetext{
${ }^{*}$ Corresponding author.
}

How to cite this paper: Sadeghi, N., Oveisi, M.R., Jannat, B., Hjimahmoodi, M., Malayeri, N. and Behzad, M. (2016) Assessment of Some Heavy Metals Concentration and Antioxidant Activity in Barley Grain Cultivars and Their Malts from Iran. Journal of Agricultural Chemistry and Environment, 5, 121-131. http://dx.doi.org/10.4236/jacen.2016.53014 
age antioxidant activity was found to be significantly higher in the malt compared to barley grain; $1.584 \pm 0.596 \mathrm{mg} / \mathrm{kg}$ vs. $0.633 \pm 0.221 \mathrm{mg} / \mathrm{kg}(p<0.001)$. The mean level of copper in barley samples was significantly higher than the standard limit that needs further investigations to be controlled.

\section{Keywords}

Barley, Cadmium, Copper, Lead, Malt, Voltammetry, Zinc

\section{Introduction}

The barley (Hordeum vulgare) is one of the oldest cultivated cereal commodities of Poaceae family that also include wheat, rice and maize [1]. Barely also grows at hot areas of the world by producing new varieties of the barley, which can sustain to the temperature of that specific area [2]. Barley is used commercially for animal feed, to produce malt, for seed and for human food applications as it is rich in protein, carbohydrates, dietary fibers, minerals, and vitamins. Global industrialization and the fast shift toward urbanization could be considered as a major cause of environmental contamination with heavy metals. The concentrations of heavy metals in a plant have been found to be directly correlated with the levels of these chemicals in the soil and atmosphere of the planting location [3]-[5]. The term "heavy metals" used when the human healthcare, environmental health and sanitation are regarded, refers to metals such as lead, mercury, copper, cadmium, nickel, chromium and etc., elements forming various compounds that impose significant threat to the environment and the human's health [6]. The food, the water we drink, the air we breathe and in almost everything we are in contact with every day contains some levels of these toxins [7]. In this regard, water and food contamination is now considered as a major nutritional health issue due to the eminent industrial growth and the consequential extensive application of chemicals [8]. These elements cannot be metabolized in our bodies, are not excreted and so they deposit and accumulate in the tissues such as muscles, fat, bones and joints that can cause various health issues and different complications [9]. Therefore, an intense monitoring system should be developed for measuring the levels of these toxins in our food in order to prevent these health problems. Zinc and copper are two of the trace elements essential for the human body. Copper has been found to be vital to the health of all living organisms and since it is incorporated into a variety of proteins and metalloenzymes, it is particularly essential to the metabolic functions in the human body [10]. It has been found to be necessary for the proper growth, development and maintenance of various tissues in multiple organs. It is also involved in stimulation of immune system, promotion of tissue healing, red blood cell formation, absorption and utilization of iron, metabolism of cholesterol and glucose and the synthesis of important proteins and enzymes [11]. Zinc has also been found in approximately 100 specific enzymes, is present in transcription factors as structural ions and is stored and transferred in metallothioneins [12]. This element plays various biological roles in the human body including metabolism of RNA and DNA, gene expression, signal transduction, regulation of apoptosis, modulation of brain excitability and synaptic plasticity [13]. Both these elements are considered as antioxidants, molecules that prohibit the oxidation of other molecules; a chemical reaction through which free radicals are produced [14]. These free radicals have been found to be associated with more than one hundred disorders in the human body. They deplete antioxidants essential for the immune system, interrupt gene expression and lead to production of abnormal proteins [15]. As another outcome of the vast technological improvements and global industrialization an impressive variety of products can be seen all around the world. Of the various kinds of drinks found in the market, non-alcoholic beer is one of the most popular ones among Iranian population. This product is resulted from the malting process of barley. Therefore it is of almost importance to be aware of the levels of heavy metal contaminants; lead and cadmium in samples of barley and malt, also some nutrition trace elements; zinc and copper and total antioxidant activity. So it was aimed to measure the levels of zinc, copper, lead, cadmium and antioxidant activity in a few samples of malt and barley via polarography and FRAP method, respectively.

\section{Materials and Methods}

\subsection{Materials}

Polarography: Glacial acetic acid (K35377356546), sodium acetate (K37186665742), tartaric acid (819A135004), 
copper nitrate (6397182), lead nitrate (7397), zinc nitrate (8912071) and cadmium nitrate (211B981619) were purchased from Merck (Germany) and nitric acid (65\%) was acquired from Applichem (Germany).

FRAP: Hydrochloric acid (100317), Iron (II) sulphate heptahydrate (103965), Iron (III) chloride hexahydrate (103943), 2,4,6-Tri (2-pyridyl)-1,3,5-triazine(110238).

\subsection{Polarography Measurement of Elements}

\subsubsection{Preparation of Standard Solutions}

Seventeen grams of sodium acetate trihydrate was dissolved in $30 \mathrm{~mL}$ of distilled water and $0.75 \mathrm{~g}$ of tartaric acid was added to prepare sodium acetate buffer. A sonicator device (Sonorex Rk52, Germany) was used to produce a clear and uniform solution via ultrasound waves. Glacial acetic acid was used to set the $\mathrm{pH}$ of the solution in the range of 4.6 to 4.8 and then distilled water was added to increase the volume up to $100 \mathrm{~mL}$. To prepare the standard Solutions of $\mathrm{Pb}, \mathrm{Cu}$, Cd and $\mathrm{Zn}$, respectively $0.080 \mathrm{~g} \mathrm{~Pb}\left(\mathrm{NO}_{3}\right)_{2}, 0.191 \mathrm{~g} \mathrm{Cu}\left(\mathrm{NO}_{3}\right)_{2}, 0.137 \mathrm{~g}$ $\mathrm{Cd}\left(\mathrm{NO}_{3}\right)_{2}$ and $0.214 \mathrm{~g} \mathrm{Zn}\left(\mathrm{NO}_{3}\right)_{2}$ were each dissolved in $100 \mathrm{~mL}$ double distilled deionized water. The calibration curves of the four elements through standard addition method are presented in Figure 1 \& Figure 2. Then, $10 \mathrm{~mL}$ of $\mathrm{Zn}$ standard solution and $5 \mathrm{~mL}$ from each of the $\mathrm{Pb}, \mathrm{Cu}$ and $\mathrm{Cd}$ standard solutions were combined and double distilled water was added up to $100 \mathrm{~mL}$ to prepare the quadruple standard solution of $\mathrm{Zn}, \mathrm{Cu}, \mathrm{Pb}$ and $\mathrm{Cd}$. The concentrations of $\mathrm{Zn}, \mathrm{Cu}, \mathrm{Cd}$ and $\mathrm{Pb}$ in the mentioned solution were then calculated to be $47.085 \mu \mathrm{g} / \mathrm{mL}$, $25.197 \mu \mathrm{g} / \mathrm{mL}, 25.054 \mu \mathrm{g} / \mathrm{mL}$ and $24.992 \mu \mathrm{g} / \mathrm{mL}$, respectively.

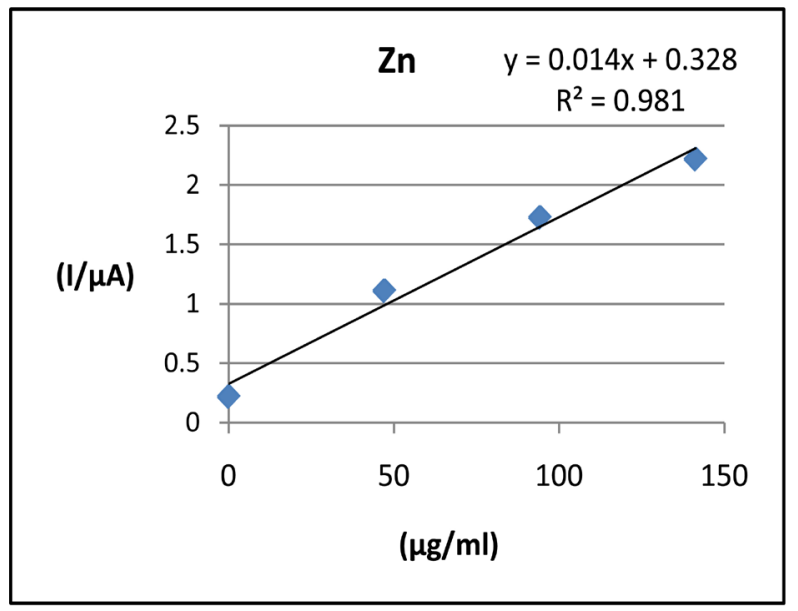

(a)

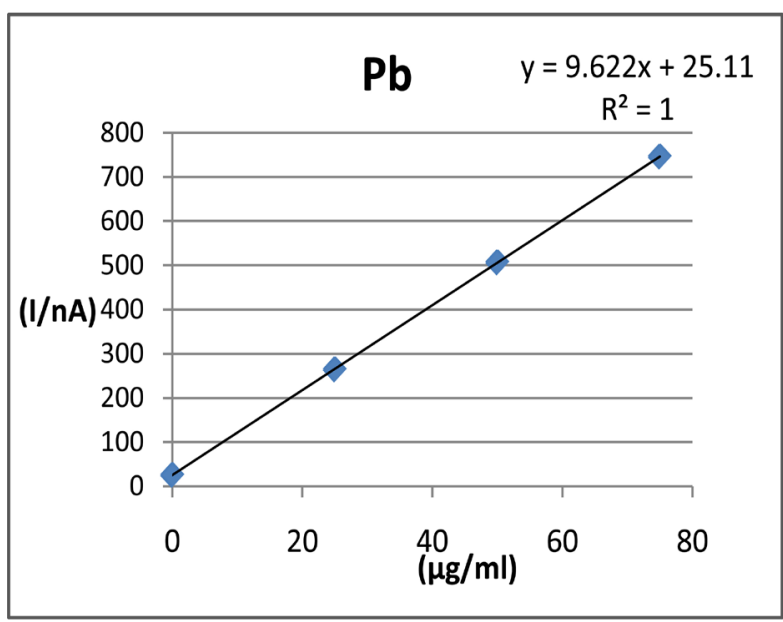

(c)

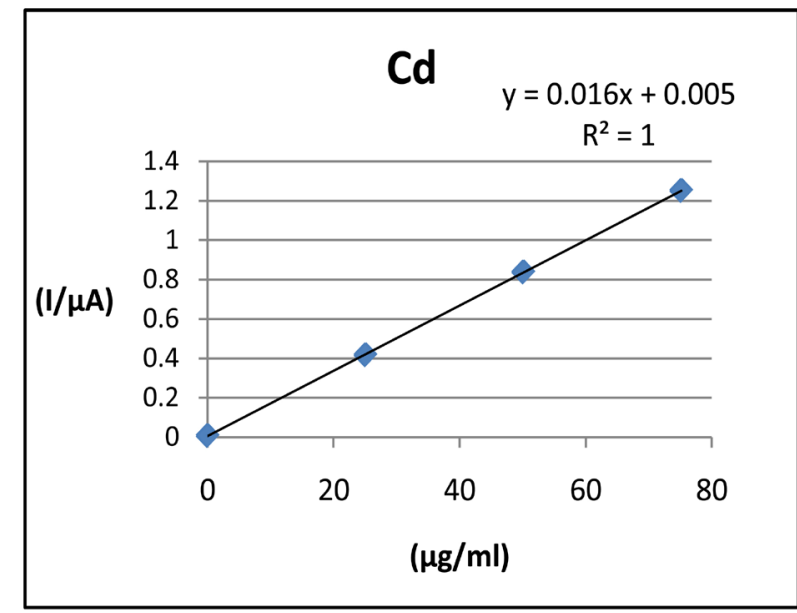

(b)

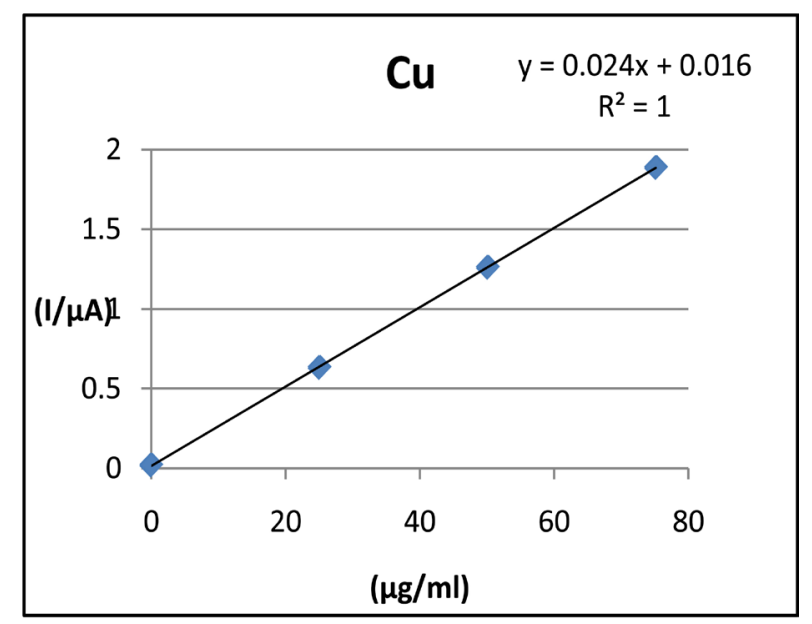

(d)

Figure 1. Calibration curves of (a) Zn, (b) Cd, (c) Pb and (d) Cu using standard addition method for barley. 


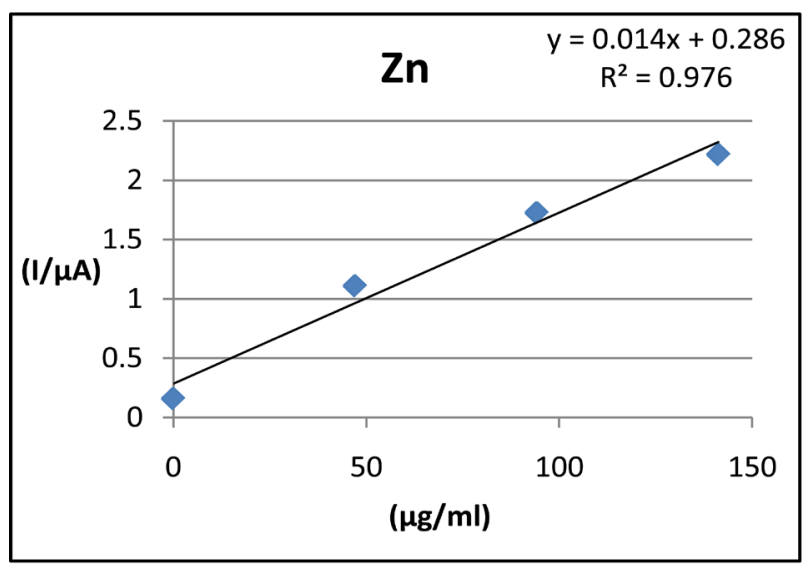

(a)

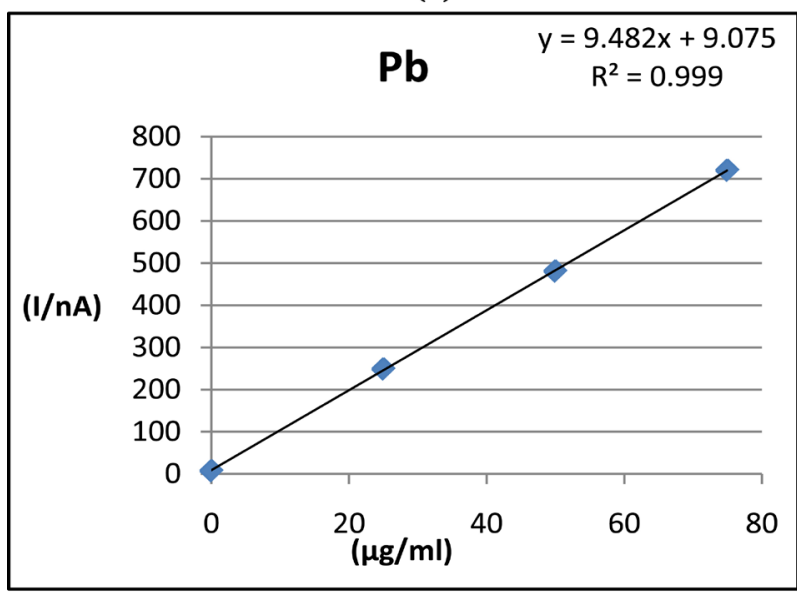

(c)

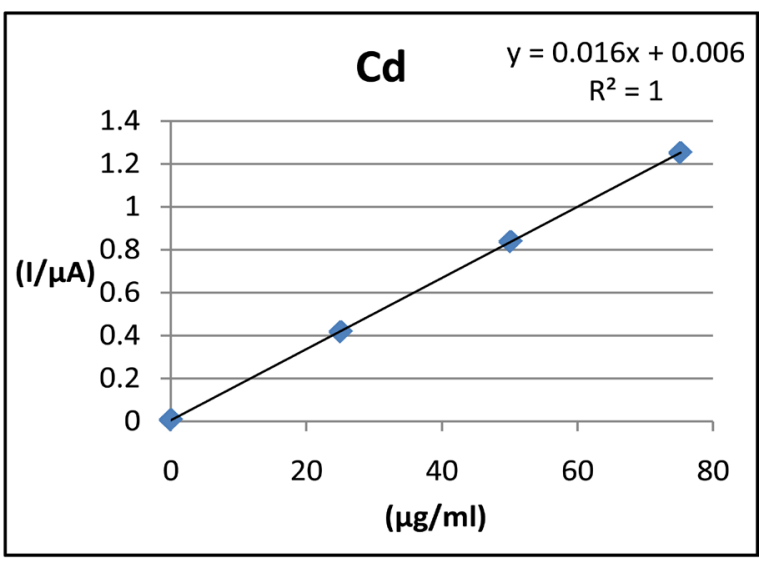

(b)

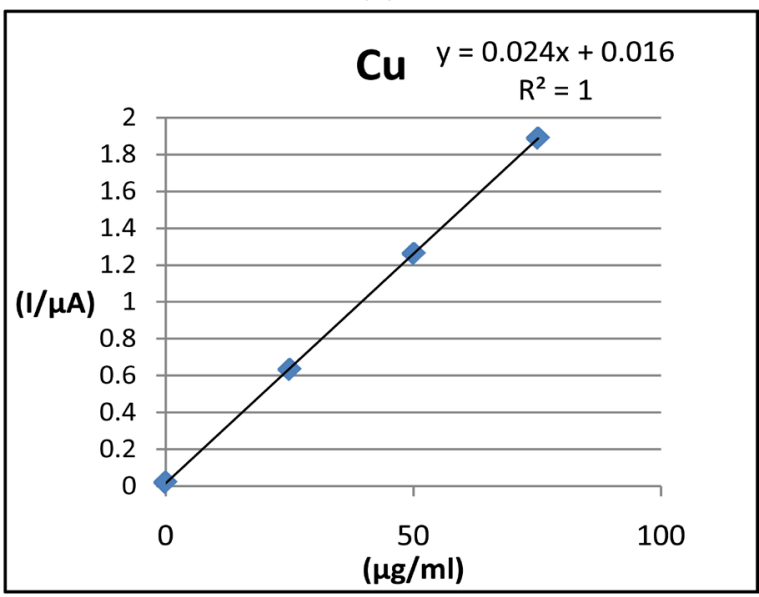

(d)

Figure 2. Calibration curves of (a) Zn, (b) Cd, (c) Pb and (d) Cu using standard addition method for malt.

\subsubsection{Sampling and Preparation}

The barley cultivars were collected from the seed and plant improvement institute which included 19 Iranian barley cultivars: (Bahman, MB-82-12, Nosrat, Kavir, Torkman, Makoeei, Karoun, Valfajr, Rihane, Dasht, MB-42-4, Nik, Rihane-03, Sahra, Yosef, DD-10, Nimrooz, Fajr-30, Gorgan-4). These cultivars were collected from the growing area of Iran and corresponding malts were studied. Two grams of each sample were heated to turn into dry ashes, which were dissolved in $10 \mathrm{~mL}$ of $65 \%$ Nitric acid. The samples were heated in a furnace at the temperature of $450^{\circ} \mathrm{C}$ to produce dry ashes, a procedure known as digestion. The ashes were added to $1 \mathrm{~mL}$ of $65 \% \mathrm{Nitric}$ acid and $9 \mathrm{~mL}$ of deionized water and the solutions were boiled. After cooling, they were filtered and their volumes were brought to $25 \mathrm{~mL}$. Then $10 \mathrm{~mL}$ of sodium acetate buffer and three doses of $100 \mu \mathrm{L}$ quadruple standard solution were added to each sample solution and $500 \mu \mathrm{L}$ of the final product was presented to the device for analysis via the 746 VA trace analyzer. Concentrations were measured 3 times and the acquired data were then analyzed.

\subsubsection{Measurement}

The polarograph's cell was filled with $10 \mathrm{~mL}$ of sodium acetate buffer and the solution was stirred at $2000 \mathrm{rpm}$ for 60 seconds. Measuring began with drawing a baseline using a Hanging Drop Mercury Electrode (HDME). The volume of the drop was $5 \mu \mathrm{L}$ and a pulse with a height of $50 \mathrm{mV}$ and a width of 40 ms was used. Primary electrolysis was performed with a potential of $800 \mathrm{mV}$ applied for $90 \mathrm{~s}$. The stirring was stopped for $10 \mathrm{~s}$ during the resting phase so that the solution would be ready for measurements. The voltage was changed from $800 \mathrm{mV}$ to $100 \mathrm{mV}$ with a scan rate of $60 \mathrm{mV} / \mathrm{s}$ and $6 \mathrm{mV}$ steps. After the baseline the baseline was drawn, $500 \mu \mathrm{L}$ of the prepared solution was added to the cell and stirred for $100 \mathrm{~s}$ at $2000 \mathrm{rpm}$. The mentioned processes were repeated in the next phases to obtain the voltamogram. Afterwards, $100 \mu \mathrm{L}$ of the quadruple standard solution was 
added to the cell in three separate steps, between each the measurements were repeated. The device calculated the average of the three measurements for the analysis. Polarogram curves of the four elements drawn by the device for barley and malt samples are depicted in Figure 3 \& Figure 4 respectively.

\subsection{Antioxidant Activity Measurement}

In order to measure antioxidant activity of the samples, ferric reducing antioxidant (FRAP) assay was conducted by mixing and incubating $10 \mu \mathrm{L}$ of barley or malt extracts with $90 \mu \mathrm{L}$ of distilled water and $900 \mu \mathrm{L}$ of FRAP reagent. Spectrophotometry was used for measuring antioxidant activity at $593 \mathrm{~nm}$ after half an hour (GBC Cintra 40, Victoria, Australia). Calibration curves were constructed using $\mathrm{FeSO}_{4}$ concentrations of 1000, 750, 500, 250 and $125 \mu \mathrm{M}$. All measurements were repeated three times [16].

\subsection{Statistical Analysis}

SPSS v.20 was used for data entry and analysis, during which the measured concentrations were compared to the standard limits presented by the Food and Agriculture Organization/World Health Organization (FAO/WHO) [17] via T-Test.

\section{Results}

The minimum amounts of $\mathrm{Zn}, \mathrm{Cu}, \mathrm{Pb}$ and $\mathrm{Cd}$ that could be measured via the Differential Pulse Anodic Stripping Voltammetry (DPASV) method applied in this survey were calculated to be $0.05 \mathrm{mg} / \mathrm{kg}, 0.01 \mathrm{mg} / \mathrm{kg}, 0.005$ $\mathrm{mg} / \mathrm{kg}$ and $0.005 \mathrm{mg} / \mathrm{kg}$, respectively. The accuracy of measurements were calculated based on the three mea-

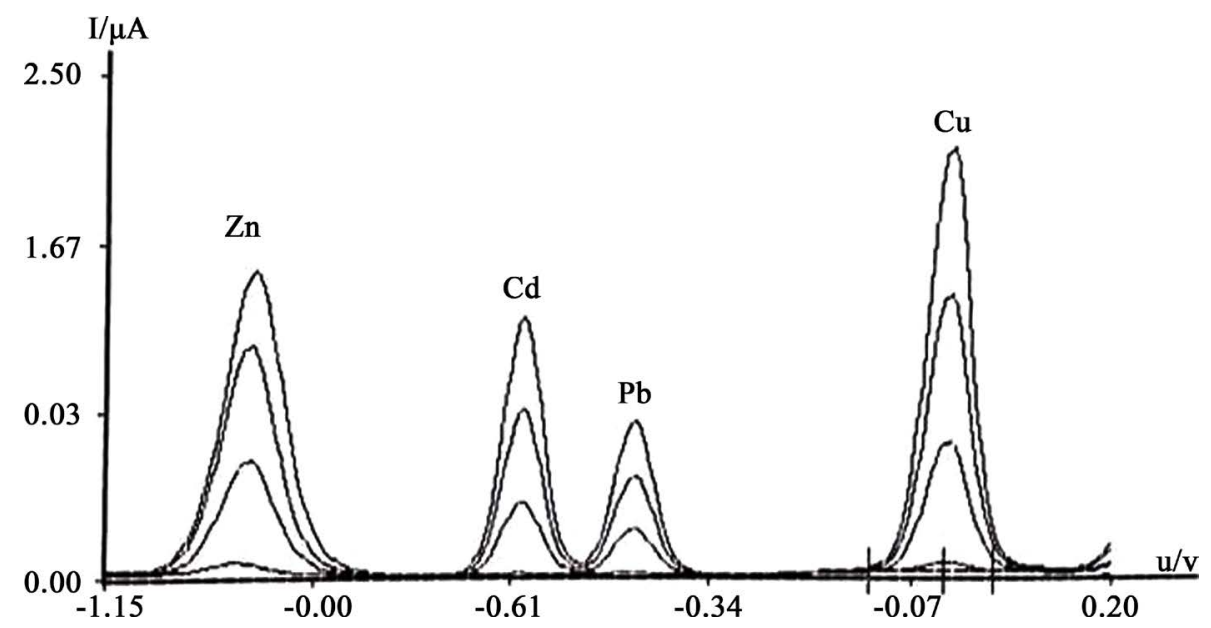

Figure 3. Polarogram Curves of the four element in barley samples.

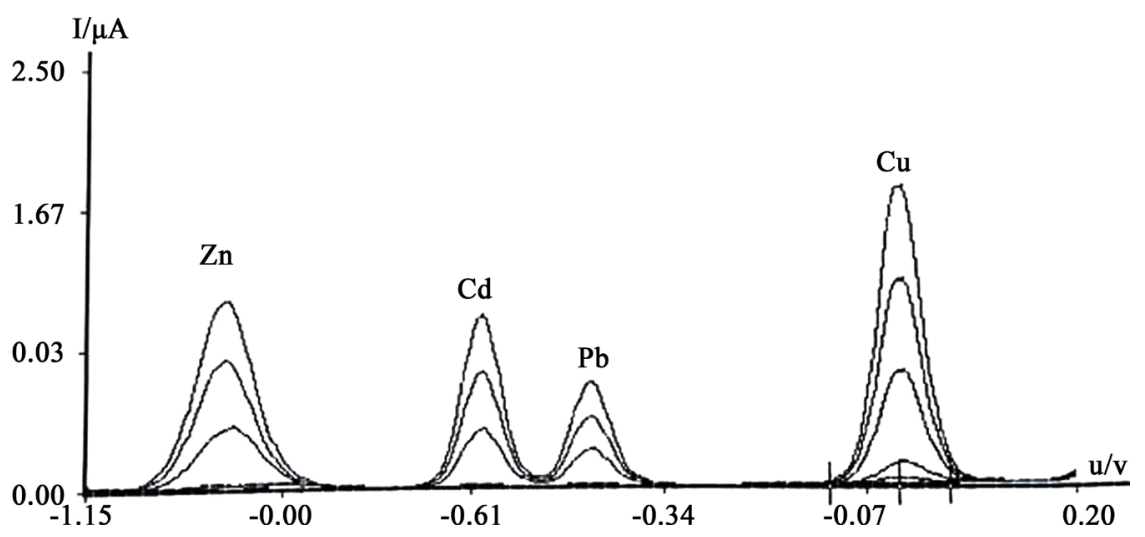

Figure 4. Polarogram Curves of the four elements in malt samples. 
surements for each element using standard errors and were found to be $5.6 \%, 3.2 \%$, 3.5\% and $4.5 \%$ for the mentioned elements respectively.

Table 1 presents the concentration of each element in our evaluated samples and Table 2 demonstrates the average of measured amounts of elements in both barley and malt samples in $\mathrm{mg} / \mathrm{kg}$. The second column of the table shows the standard limits of each element determined by FAO/WHO, which were similar for barley and malt. The mean levels of $\mathrm{Zn}, \mathrm{Cd}, \mathrm{Pb}$ and $\mathrm{Cu}$ were measured to be $18.813 \pm 8.575,0.212 \pm 0.116,0.278 \pm 0.163$, $3.746 \pm 1.118 \mathrm{mg} / 100 \mathrm{~g}$ in the barley samples and 14.364 $\pm 6.391,0.153 \pm 0.098,0.179 \pm 0.082$ and $3.033 \pm$ $1.392 \mathrm{mg} / 100 \mathrm{~g}$ in the malt samples, respectively as shown in Figure 5. As presented the levels of $\mathrm{Zn}$ and $\mathrm{Pb}$ were significantly lower than their standard limits in our barley samples. The level of Cd was found to be slightly higher than the determined limit but the difference was statistically insignificant. Only the level of $\mathrm{Cu}$ was measured to be considerably higher than the standard limit of $3 \mathrm{mg} / \mathrm{kg}$ presented by FAO/WHO $(P$ value $=$ 0.008). The concentration of Zn was found to be lowest and highest in Nimrooz and Bahman samples, respectively. The concentration of Cd was lowest in the DD-10 sample and highest in the Bahman sample. The concentration of $\mathrm{Pb}$ was lowest in the Nosrat and Sahra samples and highest in the Torkman sample. Nimrooz had the lowest concentration of $\mathrm{Cu}$ and the highest concentration of this element was found in Kavir sample. As for the evaluated malt samples the levels of $\mathrm{Zn}, \mathrm{Cd}$ and $\mathrm{Pb}$ were reported to be significantly lower than the standard

Table 1. The average amount of each element measured in barley and malt samples in $\mathrm{mg} / \mathrm{kg}$, compared standard values.

\begin{tabular}{cccccc}
\hline \multirow{2}{*}{ Element } & Standard Limit & \multicolumn{2}{c}{ Barley } & \multicolumn{2}{c}{ Malt } \\
\cline { 3 - 6 } & 27 & $($ Mean \pm SD) & $P$ value & (Mean \pm SD) & $P$ value \\
\hline $\mathrm{Zn}$ & 0.21 & $18.813 \pm 8.575$ & $<0.001$ & $14.364 \pm 6.391$ & $<0.001$ \\
$\mathrm{Cd}$ & 0.43 & $0.212 \pm 0.116$ & 0.912 & $0.153 \pm 0.098$ & 0.020 \\
$\mathrm{~Pb}$ & 3 & $0.278 \pm 0.163$ & 0.001 & $0.179 \pm 0.082$ & $<0.001$ \\
$\mathrm{Cu}$ & & $3.746 \pm 1.118$ & 0.008 & $3.033 \pm 1.392$ & 0.915 \\
\hline
\end{tabular}

Table 2. Concentration of the four elements in the evaluated samples of barley and malt. (mg/kg).

\begin{tabular}{|c|c|c|c|c|c|c|c|c|}
\hline \multirow{2}{*}{ Variety } & \multicolumn{4}{|c|}{ Barley (Mean \pm SD) } & \multicolumn{4}{|c|}{ Malt (Mean \pm SD) } \\
\hline & $\mathrm{Zn}$ & $\mathrm{Cd}$ & $\mathrm{Pb}$ & $\mathrm{Cu}$ & $\mathrm{Zn}$ & $\mathrm{Cd}$ & $\mathrm{Pb}$ & $\mathrm{Cu}$ \\
\hline Rihane-03 & $12.53 \pm 2.21$ & $0.28 \pm 0.03$ & $0.32 \pm 0.04$ & $4.19 \pm 0.98$ & $20.82 \pm 5.26$ & $0.06 \pm 0.01$ & $0.17 \pm 0.024$ & $0.86 \pm 0.09$ \\
\hline Makoiee & $28.60 \pm 5.42$ & $0.10 \pm 0.03$ & $0.34 \pm 0.03$ & $4.04 \pm 0.16$ & $10.92 \pm 2.34$ & $0.24 \pm 0.08$ & $0.25 \pm 0.02$ & $1.94 \pm 0.13$ \\
\hline Mb-82-12 & $18.79 \pm 4.13$ & $0.28 \pm 0.05$ & $0.39 \pm 0.06$ & $3.94 \pm 0.23$ & $17.41 \pm 5.32$ & $0.24 \pm 0.067$ & $0.20 \pm 0.03$ & $2.40 \pm 0.45$ \\
\hline Gorgan & $21.94 \pm 3.89$ & $0.40 \pm 0.06$ & $0.43 \pm 0.07$ & $3.84 \pm 0.67$ & $17.75 \pm 4.39$ & $0.03 \pm 0.09$ & $0.11 \pm 0.01$ & $2.14 \pm 0.67$ \\
\hline Mb-82-4 & $7.40 \pm 1.96$ & $0.25 \pm 0.05$ & $0.15 \pm 0.02$ & $3.76 \pm 0.94$ & $28.00 \pm 8.34$ & $0.32 \pm 0.03$ & $0.22 \pm 0.05$ & $5.24 \pm 1.09$ \\
\hline Karoun & $19.13 \pm 3.67$ & $0.19 \pm 0.01$ & $0.32 \pm 0.06$ & $4.07 \pm 0.66$ & $16.85 \pm 4.58$ & $0.05 \pm 0.01$ & $0.08 \pm 0.01$ & $3.88 \pm 0.84$ \\
\hline Dasht & $12.17 \pm 2.45$ & $0.08 \pm 0.01$ & $0.17 \pm 0.03$ & $4.15 \pm 0.49$ & $22.27 \pm 4.67$ & $0.22 \pm 0.03$ & $0.26 \pm 0.06$ & $3.82 \pm 0.62$ \\
\hline Nik & $25.43 \pm 4.69$ & $0.29 \pm 0.06$ & $0.17 \pm 0.02$ & $3.48 \pm 0.94$ & $24.06 \pm 5.12$ & $0.08 \pm 0.01$ & $0.27 \pm 0.07$ & $5.22 \pm 1.23$ \\
\hline Fajr30 & $10.60 \pm 2.67$ & $0.22 \pm 0.098$ & $0.54 \pm 0.043$ & $5.60 \pm 0.90$ & $15.00 \pm 3.95$ & $0.19 \pm 0.02$ & $0.15 \pm 0.01$ & $3.32 \pm 0.83$ \\
\hline Yosef & $26.80 \pm 5.37$ & $0.13 \pm 0.08$ & $0.54 \pm 0.06$ & $3.68 \pm 0.38$ & $13.91 \pm 2.94$ & $0.17 \pm 0.02$ & $0.15 \pm 0.01$ & $3.18 \pm 0.92$ \\
\hline DD -10 & $7.80 \pm 1.96$ & $0.04 \pm 0.01$ & $0.11 \pm 0.01$ & $3.75 \pm 0.49$ & $12.25 \pm 1.96$ & $0.21 \pm 0.03$ & $0.27 \pm 0.03$ & $3.60 \pm 0.75$ \\
\hline Nosrat & $11.60 \pm 2.31$ & $0.32 \pm 0.03$ & $0.10 \pm 0.01$ & $3.70 \pm 0.87$ & $10.71 \pm 2.64$ & $0.27 \pm 0.03$ & $0.21 \pm 0.02$ & $3.44 \pm 0.77$ \\
\hline Sahra & $18.73 \pm 3.97$ & $0.09 \pm 0.01$ & $0.10 \pm 0.06$ & $4.05 \pm 0.81$ & $9.64 \pm 1.68$ & $0.08 \pm 0.04$ & $0.20 \pm 0.03$ & $3.28 \pm 0.69$ \\
\hline Kavir & $23.70 \pm 7.21$ & $0.32 \pm 0.02$ & $0.16 \pm 0.04$ & $5.11 \pm 0.26$ & $6.24 \pm 2.34$ & $0.18 \pm 0.016$ & $0.34 \pm 0.06$ & $1.08 \pm 0.23$ \\
\hline Bahman & $32.06 \pm 4.35$ & $0.39 \pm 0.02$ & $0.14 \pm 0.02$ & $1.64 \pm 0.19$ & $16.89 \pm 4.45$ & $0.07 \pm 0.04$ & $0.06 \pm 0.01$ & $2.90 \pm 0.51$ \\
\hline Torkaman & $26.30 \pm 3.51$ & $0.12 \pm 0.06$ & $0.62 \pm 0.03$ & $4.93 \pm 0.84$ & $11.18 \pm 2.68$ & $0.22 \pm 0.05$ & $0.25 \pm 0.05$ & $5.66 \pm 1.09$ \\
\hline Valfajr & $31.32 \pm 6.89$ & $0.09 \pm 0.09$ & $0.11 \pm 0.01$ & $3.73 \pm 0.95$ & $7.73 \pm 1.64$ & $0.04 \pm 0.01$ & $0.06 \pm 0.08$ & $2.98 \pm 0.95$ \\
\hline Rihan & $20.62 \pm 6.94$ & $0.36 \pm 0.036$ & $0.35 \pm 0.06$ & $4.53 \pm 0.68$ & $3.98 \pm 0.95$ & $0.32 \pm 0.07$ & $0.09 \pm 0.01$ & $3.39 \pm 0.86$ \\
\hline Nimroz & $1.10 \pm 0.46$ & $0.25 \pm 0.06$ & $0.27 \pm 0.08$ & $1.28 \pm 0.74$ & $5.68 \pm 1.10$ & $0.03 \pm 0.01$ & $0.06 \pm 0.01$ & $0.86 \pm 0.08$ \\
\hline
\end{tabular}




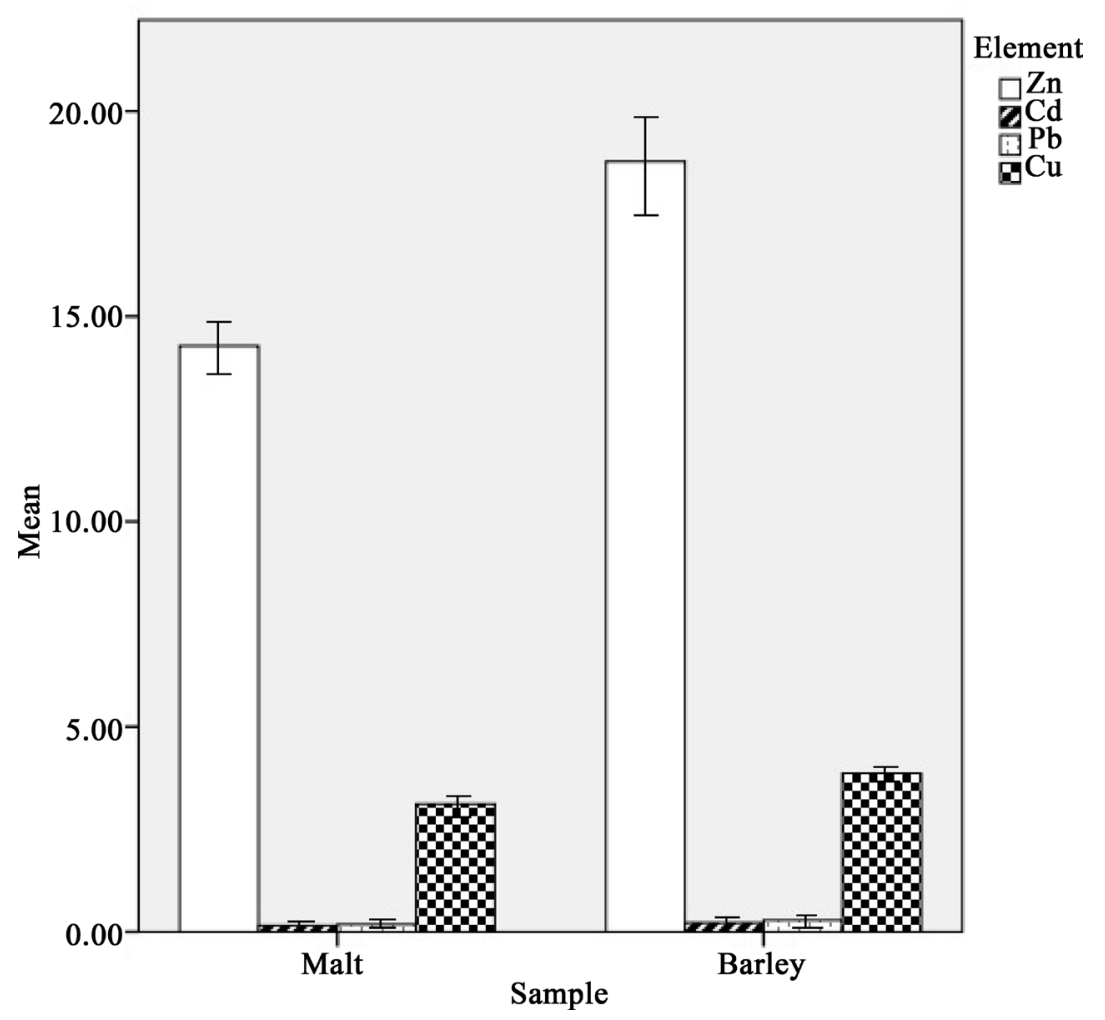

Figure 5. The mean levels of the four elements comparison in barley and malt samples ( $P$ values over the bars) $(\mathrm{mg} / \mathrm{kg})$.

limits while the level of $\mathrm{Cu}$ was slightly higher than limit of $3 \mathrm{mg} / \mathrm{kg}$. However, the difference was not significant $(P$ value $=0.915)$. The highest concentration of $\mathrm{Zn}$ was found in Mb-42-4 sample and the lowest concentration was measured in Rihane sample. Nimrooz had the lowest concentration of $\mathrm{Cd}$ and its highest concentration was found in the Mb-42-4 and Rihane samples. Nimrooz, Valfajr and Bahman samples had the lowest concentration of $\mathrm{Pb}$, and the highest concentration was found in the Kavir sample. Nimrooz and Rihane-03 samples had the lowest concentration of $\mathrm{Cu}$ and its highest concentration was measured in the Mb-42-4 sample. As for the antioxidant activity, the measured figures in barley and malt samples ranged from $0.31-1.01 \mathrm{mg} / \mathrm{kg}$ and 0.64 $3.34 \mathrm{mg} / \mathrm{kg}$, respectively. The average activity was found to be significantly higher in malt compared to barley grain which was $1.584 \pm 0.596 \mathrm{mg} / \mathrm{kg}$ vs. $0.633 \pm 0.221 \mathrm{mg} / \mathrm{kg}(P$ value $<0.001)$. The activities of different cultivars of our samples are presented in Figure 6.

\section{Discussion}

Rapidly spiking growth of various industries have resulted in an extensive application of chemical compounds, causing an imbalance in the natural cycling of chemicals in the ecosystem. The outcome has been the global environmental pollution [9]. These toxins, particularly heavy metals, have entered the food chains and as the highest level in these chains, humans are extremely susceptible to accumulation of these chemicals in their bodies and their toxic effects [8]. Therefore, intense monitoring systems have been developed to assess the food and water consumed by the people. On this note, many organizations have evaluated the maximum level of these elements that are safe for the human body and have proposed standard limits for each element. Food and Agriculture Organization/World Health Organization (FAO/WHO) has published one of the reliable guidelines on this subject [17]. As mentioned, heavy metals have found their ways into the soil, water and atmosphere and through these routes can enter the plants and finally our bodies. Therefore, the plants are valid indicators of the heavy metal contamination in each area and should be intensely monitored in order to prevent entering of these toxins into our bodies. Another route from which toxins can enter our nutrition is through the process our foods are produced. As for the highly consumed non-alcoholic beverages in Iran, these drinks are produced from the malting process of barley. So the safety of these products can be monitored at multiple levels, two of which are 


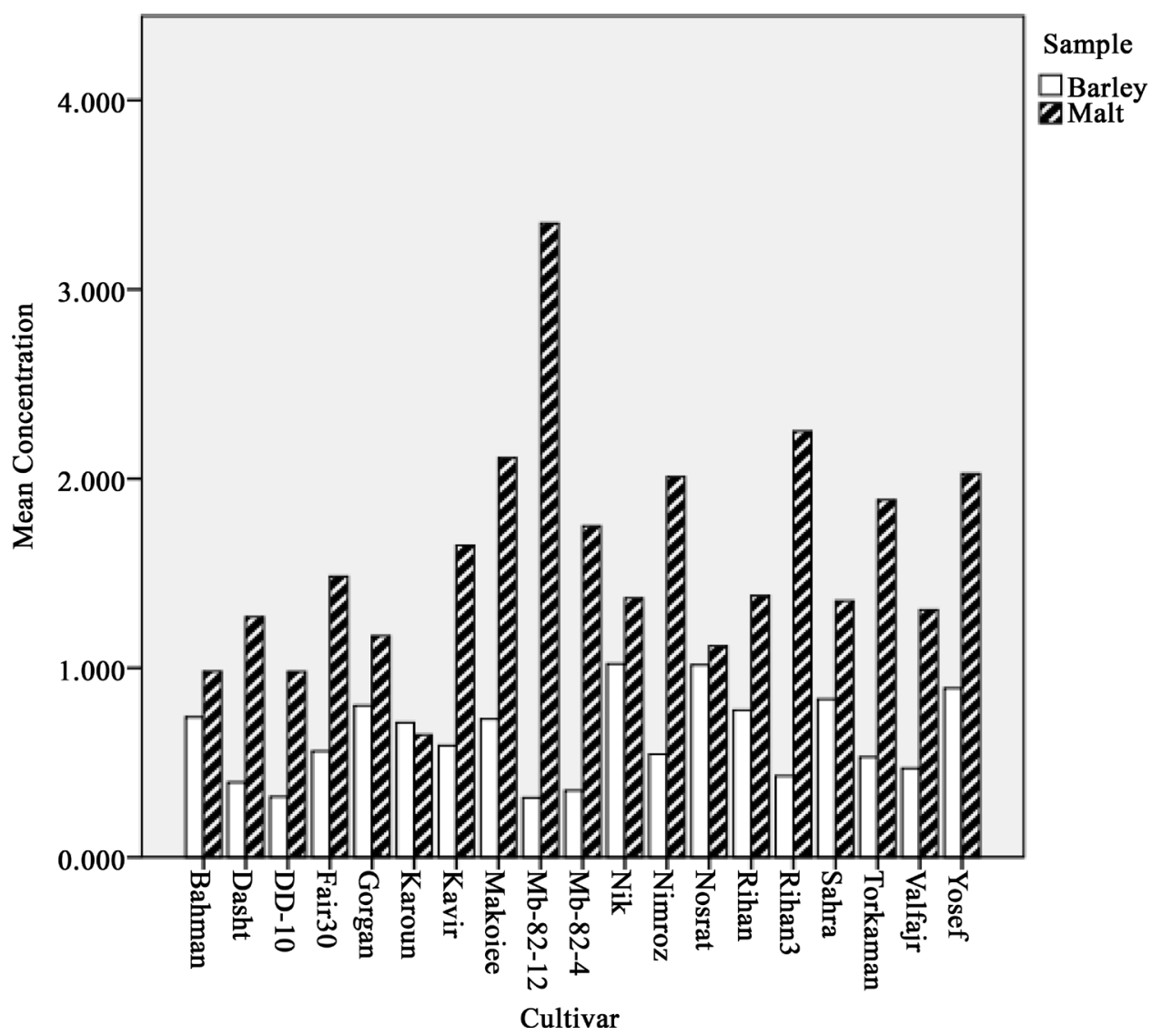

Figure 6. Antioxidant activity in different samples of barley and their malt (mg/kg).

the barley itself and the malt that is produced from it. Accordingly, in this study, it was aimed to evaluate the concentration of $\mathrm{Zn}, \mathrm{Pb}, \mathrm{Cu}$ and $\mathrm{Cd}$ as four of the most common poisonous heavy metals in barley and malt samples used for production of non-alcoholic beer in Iran, since no similar studies have been performed yet.

Our results showed that the level of $\mathrm{Cu}$ in the evaluated barley samples significantly exceeded the safe limits recommended by FAO/WHO guidelines, whereas the concentrations of the other elements in both barley and malt samples were either within the normal limits or slightly higher than the standard limit, which was reported to be insignificant. These findings imply the necessity of a more precise and strict monitoring on cultivation of barley in Iran. The source of such trace elements must be detected and controlled. This is the first study evaluating the levels of $\mathrm{Zn}, \mathrm{Pb}, \mathrm{Cd}$ and $\mathrm{Cu}$ in barley and malt samples in Iran. However, similar studies have been conducted to evaluate the concentration of heavy metals in barley or malt samples in other countries. For instance in 2002, Malmauret et al. reported the level of Cd in barley samples acquired from France to be 0.008 - 0.036 $\mathrm{mg} / \mathrm{kg}$, which was significantly lower than the level of this element in our barley samples [18]. In the same year, Wu et al. measured the level of $\mathrm{Pb}$ in barley samples from China to be $0.02-0.48 \mathrm{mg} / \mathrm{kg}$ that was quite similar to the level of this element measured in our study [19]. In another study from the same year by Vinas et al., the levels of $\mathrm{Cu}$ and $\mathrm{Pb}$ in barley samples from Spain were reported to be 0.06 and $0.16 \mathrm{mg} / \mathrm{kg}$, both significantly lower than our findings [20]. In 2004, Zhao et al. reported the levels of Cd and $\mathrm{Pb}$ in samples of barley from Britain to be considerably lower than our samples, respectively $0.02-0.046$ and $0.06-0.12 \mathrm{mg} / \mathrm{kg}$ [21]. Briggs et al. reported the levels of $\mathrm{Cd}, \mathrm{Cu}, \mathrm{Pb}$ and $\mathrm{Zn}$ in Malt samples to be $0.007,3.5,0.04$ and $24 \mathrm{mg} / \mathrm{kg}$, respectively [22]. In comparison, the levels of $\mathrm{Cd}$ and $\mathrm{Pb}$ were lower in their samples, while the level of $\mathrm{Zn}$ in our malt samples was considerably lower than theirs. The level of $\mathrm{Cu}$ was quite similar in the two surveys. In another study Adams et al. measured the levels of these elements in malt samples to be respectively 0.018, 2.55, 0.03 and 23.6 $\mathrm{mg} / \mathrm{kg}$. Similar to the previous study, the level of Zn in Adams's survey was also higher than the level of this element in our study, while the other three metals were significantly lower than ours [23]. In another survey from England in 2006, Baxter et al. measured the levels of Cd and Cu to be $0.003-0.007$ and $5.7-6.2 \mathrm{mg} / \mathrm{kg}$ in 
barley samples and 0.001 and $5.8-6.2 \mathrm{mg} / \mathrm{kg}$ in malt samples [24]. Compared to these figures, the levels of $\mathrm{Cu}$ were significantly lower in barley and malt samples of our study, while the levels of $\mathrm{Cd}$ were higher in our samples. One year later Shar et al. reported the levels of $\mathrm{Cd}, \mathrm{Cu}, \mathrm{Pb}$ and $\mathrm{Zn}$ in barley samples acquired from Pakistan to range from $0.22-1.95,6.29$ - 35.03, $0.82-5.64$ and $24.82-95.31 \mathrm{mg} / \mathrm{kg}$, respectively [25]. All of these figures were higher than the levels of these elements in our samples. The levels of $\mathrm{Cd}, \mathrm{Cu}$ and $\mathrm{Zn}$ in barley samples from China were reported by Chen et al. to be $0.023-0.091,3.45-6.33,35.85-76.10 \mathrm{mg} / \mathrm{kg}$ [26]. Compared to our reports the level of $\mathrm{Cd}$ was lower, the level of $\mathrm{Cu}$ was quite similar and the level of $\mathrm{Zn}$ was significantly higher in their samples. In 2011, Cejka et al. measured the levels of $\mathrm{Cd}, \mathrm{Cu}$ and $\mathrm{Zn}$ in barley samples from Prague to be 1.21, 1.1 - 11.3 and 4.6 - $16.6 \mathrm{mg} / \mathrm{kg}$ [27]. The mean level of Cu was higher in our samples, while for the other elements it was the otherwise. Similar assessments were performed on barley and malt samples acquired from Ethiopia by Eticha et al. in 2015. According to their reports the levels of $\mathrm{Cd}, \mathrm{Cu}, \mathrm{Pb}$ and $\mathrm{Zn}$ were $0.318,5.238-6.9,0.775$ and $29.4-33.25 \mathrm{mg} / \mathrm{kg}$ in barley samples and the levels of $\mathrm{Cu}$ and $\mathrm{Zn}$ in malt samples were 6.038 and $33.088 \mathrm{mg} / \mathrm{kg}$ [28]. As can be seen the levels of all these elements in both barley and malt samples were significantly higher in their study compared to ours. The concentration of each element varies considerably between various samples obtained in this study. These differences might be due to the difference in various cultivating parameters such as soil, water, climate of the location and etc. The differences observed between various malt samples could also be attributed to the differences in brewing-related factors. These were only a few examples of the countless surveys evaluating the levels of heavy metals and toxins in nutritional products that highlight the utmost importance of this matter and its undeniable effects on our health. We also evaluated the antioxidant activity of barley and malt samples and the average activity was found to be significantly higher in malt compared to barley grain. Similar results have been reported by Mahmoudi et al. [16]. Zn and $\mathrm{Cu}$ are two of the trace elements, found to exert antioxidant activities. Although these two elements are measured to be at higher concentrations in the barley cultivars, the antioxidant activity was reported to be higher in the malt samples. Accordingly, the antioxidant characteristics of these samples cannot be attributed to their contents of $\mathrm{Zn}$ and $\mathrm{Cu}$, or otherwise the antioxidant activity of barley cultivars should have been higher than their malts. The observed increase in antioxidant activity of malt was previously suggested to be coming from the development of non-enzymatic browning products such as Millard products, particularly melanoidins that can present with antioxidant activities [29]-[32]. Hydrolytic enzymes can also enhance the release of bound phenolic compounds, most commonly the phenolic acids related to lignin and arabinoxylans [33] [34]. The kilning process through which the malt samples are produced can also break the outer tissues of the grains and allow better extraction of phenolic acids [34] [35]. These might be the reasons for the higher antioxidant activity observed in malt samples compared to their barley grains.

\section{Conclusion}

The results of this study showed that the levels of $\mathrm{Cd}$ in barley samples and $\mathrm{Cu}$ in samples of malt were slightly higher than the standard limits but the differences were not statistically significant. However, the level of Cu in barley samples was found to be significantly higher than the maximum safe limit determined by FAO/WHO. Further investigations are required to detect the source of this excessive $\mathrm{Cu}$ in our plants and measures must be taken to control this trace element and keep the level of $\mathrm{Cu}$ in barley samples within safe limits.

\section{Acknowledgements}

This work was student thesis and supported by grant (No.: 95-01-33-29824), from Tehran University of Medical Sciences.

\section{References}

[1] Harlan, J.R. (1979) On the Origin of Barley. USDA Agricultural Handbook 338, Washington DC, 10-36.

[2] Hoppner, K.H., Owen, B.D. and Sosulski, F.W. (1986) Proximate Principles and B-Vitamins in Saskatchewan Feed Grains. Canadian Journal of Animal Science, 48, 135-143. http://dx.doi.org/10.4141/cjas68-019

[3] Voutsa, D., Grimanis, A. and Samara, C. (1996) Trace Elements in Vegetables Grown in an Industrial Area in Relation to Soil and Air Particulate Matter. Environmental Pollution, 94, 325-335.

http://dx.doi.org/10.1016/S0269-7491(96)00088-7 
[4] Scott, D., Keoghan, J. and Allan, B. (1996) Native and Low-Input Grasses - A New Zealand High Country Perspective. New Zealand Journal of Agricultural Research, 39, 499-512. http://dx.doi.org/10.1080/00288233.1996.9513211

[5] Lake, D., Kirk, P. and Lester, J. (1984) Fractionation, Characterization, and Speciation of Heavy Metals in Sewage Sludge and Sludge-Amended Soils: A Review. Journal of Environmental Quality, 13, 175-183. http://dx.doi.org/10.2134/jeq1984.00472425001300020001x

[6] Järup, L. (2003) Hazards of Heavy Metal Contamination. British Medical Bulletin, 68, 167-182. http://dx.doi.org/10.1093/bmb/ldg032

[7] Markert, B. (1993) Plants as Biomonitors: Indicators for Heavy Metals in the Terrestrial Environment. VCH Publishers Ltd.

[8] Peralta-Videa, J.R., Lopez, M.L., Narayan, M., Saupe, G. and Gardea-Torresdey, J. (2009) The Biochemistry of Environmental Heavy Metal Uptake by Plants: Implications for the Food Chain. The International Journal of Biochemistry \& Cell Biology, 41, 1665-1677. http://dx.doi.org/10.1016/j.biocel.2009.03.005

[9] Hannon, T.B. (2014) Heavy Metal Poisoning. Health, 1, 19-20.

[10] Sigel, A., Sigel, H. and Sigel, R.K. (2013) Interrelations between Essential Metal Ions and Human Diseases. Metal Ions in Life Sciences. http://dx.doi.org/10.1007/978-94-007-7500-8

[11] Burch, R.E., Hahn, H.K. and Sullivan, J.F. (1975) Newer Aspects of the Roles of Zinc, Manganese, and Copper in Human Nutrition. Clinical Chemistry, 21, 501-520.

[12] Plum, L.M., Rink, L. and Haase, H. (2010) The Essential Toxin: Impact of Zinc on Human Health. International Journal of Environmental Research and Public Health, 7, 1342-1365. http://dx.doi.org/10.3390/ijerph7041342

[13] Hambidge, K.M. and Krebs, N.F. (2007) Zinc Deficiency: A Special Challenge. The Journal of Nutrition, 137, 11011105.

[14] Gülçin, I. (2012) Antioxidant Activity of Food Constituents: An Overview. Archives of Toxicology, 86, 345-391. http://dx.doi.org/10.1007/s00204-011-0774-2

[15] Ghasemi Pirbalouti, A., Siahpoosh, A., Setayesh, M. and Craker, L. (2014) Antioxidant Activity, Total Phenolic and Flavonoid Contents of Some Medicinal and Aromatic Plants Used as Herbal Teas and Condiments in Iran. Journal of Medicinal Food, 17, 1151-1157. http://dx.doi.org/10.1089/jmf.2013.0057

[16] Mahmoudi, T., Oveisi, M.R., Jannat, B., Behzad, M., Hajimahmoodi, M. and Sadeghi, N. (2015) Antioxidant Activity of Iranian Barley Grain Cultivars and Their Malts. African Journal of Food Science, 9, 534-539. http://dx.doi.org/10.5897/AJFS2014.1210

[17] Chandra, R., Bharagava, R., Yadav, S. and Mohan, D. (2009) Accumulation and Distribution of Toxic Metals in Wheat (Triticum aestivum L.) and Indian Mustard (Brassica campestris L.) Irrigated with Distillery and Tannery Effluents. Journal of Hazardous Materials, 162, 1514-1521. http://dx.doi.org/10.1016/j.jhazmat.2008.06.040

[18] Malmauret, L., Parent-Massin, D., Hardy, J.L. and Verger, P. (2002) Contaminants in Organic and Conventional Foodstuffs in France. Food Additives \& Contaminants, 19, 524-532. http://dx.doi.org/10.1080/02652030210123878

[19] Wu, F. and Zhang, G. (2002) Genotypic Variation in Kernel Heavy Metal Concentrations in Barley and as Affected by Soil Factors. Journal of Plant Nutrition, 25, 1163-1173. http://dx.doi.org/10.1081/PLN-120004380

[20] Viñas, P., Aguinaga, N., López-García, I. and Hernández-Córdoba, M. (2002) Determination of Cadmium, Aluminium, and Copper in Beer and Products Used in Its Manufacture by Electrothermal Atomic Absorption Spectrometry. Journal of AOAC International, 85, 736-743.

[21] Zhao, F.J., Adams, M.L., Dumont, C., McGrath, S.P., Chaudri, A.M., Nicholson, F.A., Chambers, B.J. and Sinclair, A.H. (2004) Factors Affecting the Concentrations of Lead in British Wheat and Barley Grain. Environmental Pollution, 131, 461-468. http://dx.doi.org/10.1016/j.envpol.2004.02.011

[22] Briggs, D., Boulton, A., Brookes, A. and Stevens, R. (2004) Malts, Adjuncts and Supplementary Enzymes, Brewing Science and Practice. Woodhead, Cambridge, 30-34.

[23] Adams, M., Zhao, F., McGrath, S., Nicholson, F. and Chambers, B. (2004) Predicting Cadmium Concentrations in Wheat and Barley Grain Using Soil Properties. Journal of Environmental Quality, 33, 532-541. http://dx.doi.org/10.2134/jeq2004.5320

[24] Baxter, E.D. and Hall, L. (2006) Review of Food Safety Issues Relating to the Supply and Market Acceptability of UK Malting Barley and UK Malt. Home Grown Cereals Authority.

[25] Har, G.Q., Kazi, T.G., Shar , L.A., Jamali, M.K., Afridi, H.I. and Arain, M.B. (2007) Multielement Analysis of Pakistani Barley (Hordeum vulgare L.) Varieties by Flame Atomic Absorption Spectrometry. Journal of Research (Science), 18, 69-77.

[26] Chen, F., Dong, J., Wang, F., Wu, F., Zhang, G., Li, G., Chen, Z., Chen, J. and Wei, K. (2007) Identification of Barley Genotypes with Low Grain Cd Accumulation and Its Interaction with Four Microelements. Chemosphere, 67, 2082- 
2088. http://dx.doi.org/10.1016/j.chemosphere.2006.10.014

[27] Čejka, P., Horák, T., Dvorák, J., Čulik, J., Jurková, M., Kellner, V. and Haŝková, D. (2011) Monitoring of the Distribution of Some Heavy Metals during Brewing Process. Ecological Chemistry and Engineering S, 18, 67-74.

[28] Eticha, T. and Hymete, A. (2015) Determination of Some Heavy Metals in Barley Locally Grown for Brewing and It's Malt in Ethiopia. Journal of Bioanalysis \& Biomedicine.

[29] Yilmaz, Y. and Toledo, R. (2005) Antioxidant Activity of Water-Soluble Maillard Reaction Products. Food Chemistry, 93, 273-278. http://dx.doi.org/10.1016/j.foodchem.2004.09.043

[30] Yanagimoto, K., Lee, K.G., Ochi, H. and Shibamoto, T. (2002) Antioxidative Activity of Heterocyclic Compounds Formed in Maillard Reaction Products. International Congress Series, 1245, 335-340. http://dx.doi.org/10.1016/S0531-5131(02)01007-5

[31] Goupy, P., Hugues, M., Boivin, P. and Amiot, M.J. (1999) Antioxidant Composition and Activity of Barley (Hordeum vulgare) and Malt Extracts and of Isolated Phenolic Compounds. Journal of the Science of Food and Agriculture, 79, 1625-1634. http://dx.doi.org/10.1002/(SICI)1097-0010(199909)79:12<1625::AID-JSFA411>3.0.CO;2-8

[32] Osada, Y. and Shibamoto, T. (2006) Antioxidative Activity of Volatile Extracts from Maillard Model Systems. Food Chemistry, 98, 522-528. http://dx.doi.org/10.1016/j.foodchem.2005.05.084

[33] Maillard, M.N. and Berset, C. (1995) Evolution of Antioxidant Activity during Kilning: Role of Insoluble Bound Phenolic Acids of Barley and Malt. Journal of Agricultural and Food Chemistry, 43, 1789-1793. http://dx.doi.org/10.1021/jf00055a008

[34] Maillard, M.N., Soum, M.H., Boivin, P. and Berset C. (1996) Antioxidant Activity of Barley and Malt: Relationship with Phenolic Content. LWT_Food Science and Technology, 29, 238-244. http://dx.doi.org/10.1006/fstl.1996.0035

[35] Maillard, M.N., Billaud, C., Chow, Y.N., Ordonaud, C. and Nicolas, J. (2007) Free Radical Scavenging, Inhibition of Polyphenoloxidase Activity and Copper Chelating Properties of Model Maillard Systems. LWT_Food Science and Technology, 40, 1434-1444. http://dx.doi.org/10.1016/j.lwt.2006.09.007

\section{Submit or recommend next manuscript to SCIRP and we will provide best service for you:}

Accepting pre-submission inquiries through Email, Facebook, LinkedIn, Twitter, etc.

A wide selection of journals (inclusive of 9 subjects, more than 200 journals)

Providing 24-hour high-quality service

User-friendly online submission system

Fair and swift peer-review system

Efficient typesetting and proofreading procedure

Display of the result of downloads and visits, as well as the number of cited articles

Maximum dissemination of your research work

Submit your manuscript at: http://papersubmission.scirp.org/ 